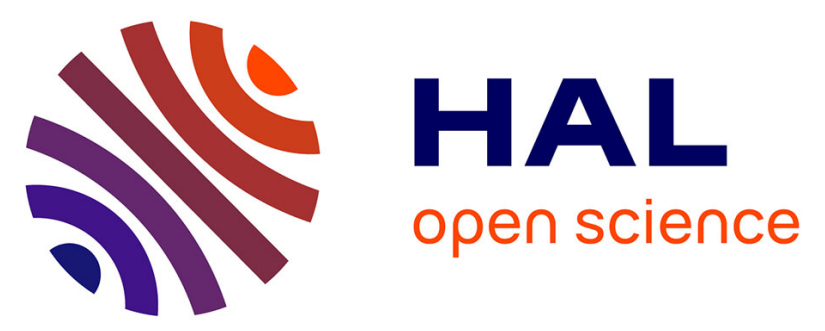

\title{
Sulforaphane potentiates oxaliplatin-induced cell growth inhibition in colorectal cancer cells via induction of different modes of cell death
}

Bettina M. Kaminski, Andreas Weigert, Bernhard Brüne, Marco Schumacher, Uwe Wenzel, Dieter Steinhilber, Jürgen Stein, Sandra Ulrich

\section{- To cite this version:}

Bettina M. Kaminski, Andreas Weigert, Bernhard Brüne, Marco Schumacher, Uwe Wenzel, et al.. Sulforaphane potentiates oxaliplatin-induced cell growth inhibition in colorectal cancer cells via induction of different modes of cell death. Cancer Chemotherapy and Pharmacology, 2010, 67 (5), pp.1167-1178. 10.1007/s00280-010-1413-y . hal-00613792

\section{HAL Id: hal-00613792 \\ https://hal.science/hal-00613792}

Submitted on 6 Aug 2011

HAL is a multi-disciplinary open access archive for the deposit and dissemination of scientific research documents, whether they are published or not. The documents may come from teaching and research institutions in France or abroad, or from public or private research centers.
L'archive ouverte pluridisciplinaire HAL, est destinée au dépôt et à la diffusion de documents scientifiques de niveau recherche, publiés ou non, émanant des établissements d'enseignement et de recherche français ou étrangers, des laboratoires publics ou privés. 


\title{
Sulforaphane potentiates oxaliplatin-induced cell growth inhibition in colorectal cancer cells via induction of different modes of cell death
}

Bettina M. Kaminski ${ }^{1}$, Andreas Weigert ${ }^{3}$, Bernhard Brüne ${ }^{3}$, Marco Schumacher ${ }^{4}$, Uwe Wenzel $^{4}$, Dieter Steinhilber ${ }^{1}$, Jürgen Stein ${ }^{1,2}$, Sandra Ulrich $^{1}$

${ }^{1}$ Institute of Pharmaceutical Chemistry, Goethe University, Frankfurt am Main, Germany, ${ }^{2}$ Department of Internal Medicine, Katharina Kasper Hospital, Frankfurt am Main, Germany, ${ }^{3}$ Institute of Biochemistry I/ZAFES, Goethe University Frankfurt am Main, Germany, ${ }^{4}$ Molecular Nutrition Research, Interdisciplinary Research Center, Justus-Liebig-University of Gießen, Germany

Address correspondence to: Sandra Ulrich, $\mathrm{PhD}$, Institute of Pharmaceutical Chemistry, Biozentrum, Goethe University, Max-von-Laue-Str. 9, 60438 Frankfurt am Main, Germany, Telephone number: +49-69-798-29341, Fax number: +49-69-798-29300, E-mail: sandra.ulrich@em.uni-frankfurt.de

\begin{abstract}
The objective of this study was to investigate, whether the plant-derived isothiocyanate Sulforaphane (SFN) enhances the anti-tumor activities of the chemotherapeutic agent oxaliplatin $(\mathrm{Ox})$ in a cell culture model of colorectal cancer. Caco-2 and SW-620 cells were cultured under standard conditions and treated with increasing concentrations of SFN [1$20 \mu \mathrm{M}]$ and/or Ox [100nM-10 $\mu \mathrm{M}]$. For co-incubation, cells were pre-treated with SFN for 24 h. Cell growth was determined by BrdU incorporation. Drug interactions were assessed using the combination-index method (CI) $(\mathrm{CK} 1$ indicates synergism). Apoptotic events were characterized by different ELISA techniques. Protein levels were examined by Western blot analysis. Annexin-V- and propidium-iodide (PI)-staining followed by FACS analysis was
\end{abstract}


used to differentiate between apoptotic and necrotic events. SFN and Ox alone inhibited cell growth of Caco-2- and SW620-cells in a dose dependent manner, an effect, which could be synergistically enhanced, when cells were incubated with the combination of both agents. Cotreated cells further displayed distinctive morphological changes that occurred during the apoptotic process, such as cell surface exposure of phosphatidylserine, membrane blebbing as well as the occurence of cytoplasmic histone-associated DNA fragments. Further observations thereby pointed towards simultaneous activation of both extrinsic and intrinsic apoptotic pathways. With increasing concentrations and treatment duration a shift from apoptotic to necrotic cell death could be observed. In conclusion, the data suggest that the isothiocyanate SFN sensitizes colon cancer cells to Ox-induced cell growth inhibition via induction of different modes of cell

Key words sulforaphane - oxaliplatin - colorectal cancer - cell growth - apoptosis

$\begin{array}{ll}\text { Abbre viations } & \\ \text { CRC } & \text { colorectal cancer } \\ \text { SFN } & \text { sulforaphane } \\ \text { Ox } & \text { oxaliplatin } \\ \text { 5-FU } & \text { 5-fluorouracil } \\ \text { CI } & \text { combination index } \\ \text { IC } & \text { half maximal inhibitory concentration } \\ \text { FCS } & \text { fetal calf serum } \\ \text { DMEM } & \text { Dulbecco's modified-Eagle's medium } \\ \text { EDTA } & \text { Ethylendiaminetetraacetic acid } \\ \text { DMSO } & \text { Dimethylsulfoxid } \\ \text { BrdU } & \text { bromodeoxyuridine }\end{array}$


TRAIL TNF-related apoptosis-inducing ligand

PARP Poly [ADP-ribose] polymerase

PI Propidium Iodide

FITC Fluorescein Isothiocyanate 


\section{Introduction}

Despite a markedly improved understanding of the disease, the advent of modern technology and rationally targeted drugs over the past years, colorectal cancer (CRC) remains a leading cause of cancer-related deaths worldwide [1]. Current treatment options involve the combination of a variety of chemotherapeutic drugs, more recently including the anticancer drug oxaliplatin $(\mathrm{Ox}) . \mathrm{Ox}$ is a third generation platinum-based drug which has shown a broad spectrum of anti-tumor activities in a wide range of cancer cell lines by disrupting DNA replication and transcription by forming intrastrand DNA adducts [2]. It further demonstrates a better safety profile than platinum-analogs of the first-(cisplatin) and second-(carboplatin)generation and is typically administered in combination with different drugs as part of specific cancer-treatment regimens, e.g. Ox plus 5-Fluoruracil and leucovorin (referred to as FOLFOX), Ox plus capecitabine (XELOX) or Ox plus cetuximab (CAPOX). Such oxaliplatin-based combination regimens show improved clinical efficacy as related to overall response rates, time to tumor progression, median overall survival in patients with metastatic colorectal cancer and especially offer an alternative treatment option against cisplatin resistant tumors $[3 ; 4 ; 5]$. However, even though conventional cancer therapies play a major role in cancer treatment, successful therapeutic outcome is often limited due to high toxicity as well as the development of multi-drug resistance. It is therefore of particular importance to investigate further drug combinations for the development of new therapeutic regimens obtaining higher efficacy, whilst, at the same time minimizing unwanted side effects, which could significantly improve patients outcome. Emerging evidence suggests that combining chemopreventive agents with chemotherapy or radiotherapy may lead to enhanced antitumor activity through synergistic action or compensation of inverse properties. Beside a multitude of synthetic substances also numerous phytochemicals have been identified to exhibit potent chemopreventive effects in different carcinogenesis models while, at the same time showing 
low toxicity [6]. SFN is a naturally occuring isothiocyanate derived from cruciferous vegetables such as broccoli, cauliflower, cabbage and kale, which targets cancer initiation and progression both in vitro and in vivo, and further induces antiproliferative and cytotoxic effects in cells that are already transformed [7]. Recently, was SFN was identified as a novel histone deacetylase inhibitor (HDACi) in colon and prostate cancer cells [8]. HDACi, as a new class of chemotherapeutic agents, show significant promise against a variety of cancers in clinical trials [9]. Most available HDACi inhibit all class I and II HDACs, thereby increasing acetylation of histone and nonhistone protein targets [10]. In vivo, histone acetylation depends on the balance between histone acetyltransferase (HAT) and histone deacetylase (HDAC), which has been proposed to play an important role in transcriptional regulation by altering chromatin structure [11]. Histone acetylation by HATs is associated with an open chromatin conformation, promoting gene transcription, whereas HDACs maintain the chromatin in the closed, transcriptionally inactive state. HDAC inhibitors have been shown to induce the expression of several tumor suppressive genes, which justifies its use in cancer prevention and therapy [12].

Several studies indicate that SFN causes growth inhibition of human cancer cells predominantly by inducing apoptosis and/or blocking cell cycle progression [13; 14]. Apoptosis is defined as an active physiologic process of cellular self-destruction, with specific morphologic and biochemical changes characterized by DNA fragmentation, cell shrinkage, nuclear condensation and membrane blebbing [15; 16]. At present, two major apoptosis pathways have been identified: the intrinsic or mitochondrial pathway and the extrinsic or death receptor-related pathway. While the extrinsic pathway is activated through cell surface death-receptors binding their respective cytokine ligands, such as TRAIL [17], the intrinsic pathway depends on mitochondrial membrane permeabilization, which causes the release of apoptogenic factors from the intermembrane space to the cytoplasm. Prevalently, both pathways result in the activation of members of the caspase family converging at the level of 
caspase-3 [18]. However, apoptotic events can also be observed in the absence of caspase-3 activation, depending on the cell type and the apoptosis initiating process [19;20]. Apart from apoptosis, alternative forms of cell death can be activated, e.g. necrosis or autophagy, which might also lead to biological consequences differing from apoptosis [21]. In the present study, we addressed the question whether plant-derived sulforaphane is able to enhance the anticarcinogenic activities of the common chemotherapy drug oxaliplatin in colorectal cancer cells with special regard to regulatory effects on the cell death machinery.

\section{Materials and Methods}

\section{Cell culture}

Caco-2 cells were kept in Dulbecco's modified Eagle's medium (DMEM), supplemented with $10 \%$ fetal calf serum (FCS), $1 \%$ penicillin/streptomycin, $1 \%$ sodium pyruvate and $1 \%$ nonessential amino acids. Human foreskin fibroblasts (HFF) were cultured in DMEM/Ham's F-12 medium supplemented with $10 \%$ FCS and $1 \%$ penicillin/streptomycin. Both cell lines were maintained at $37{ }^{\circ} \mathrm{C}$ in an atmosphere of $95 \%$ air and $5 \% \mathrm{CO}_{2}$. The cells were passaged weekly using Dulbecco's PBS containing $0.1 \%$ trypsin and $1 \%$ EDTA. The medium was changed thrice weekly. Cells were screened for possible contamination with mycoplasma at monthly intervals. For experiments, the cells were seeded onto plastic cell culture wells in serum-containing medium and allowed to attach for $24 \mathrm{~h}$. Sulforaphane (Merck Chemicals, Darmstadt, Germany) was dissolved in DMSO at a concentration of $100 \mathrm{mM}$, oxaliplatin (Sigma-Aldrich, München, Germany) was dissolved in water at a concentration of $10 \mathrm{mM}$. DMEM, DMEM/Ham's F-12 medium, DMSO, sodium pyruvate solution, penicillin and streptomycin stock solutions were all obtained from PAA Laboratories GmbH. When synergistic effects were analyzed, the cells were pre-treated with SFN for $24 \mathrm{~h}$. 
Cell Proliferation Assay

The effect of SFN, Ox or their combination on cellular DNA synthesis was assessed using a cell proliferation ELISA kit (Roche Diagnostics, Mannheim, Germany). This assay is a colorimetric immunoassay for quantification of cell proliferation based on the measurement of bromodeoxyuridine (BrdU) incorporation during DNA synthesis, and is a non-radioactive alternative to the $\left[{ }^{3} \mathrm{H}\right]$-thymidine incorporation assay. Cells were grown in 96 well culture dishes $\left(10^{3}\right.$ cells/well), incubated with SFN and/or Ox for different time intervals, and then labeled with BrdU for further four hours. Incorporated BrdU was measured colorimetrically.

Combination index (CI)

To assess the drug interactions of SFN and Ox we used the combination-index (CI) method defined by median-effect analysis of Chou and Talalay [22]. The fractional inhibitory concentration was calculated by dividing the $\mathrm{IC}_{50}$ concentration of the drug in the combination by the amount of the drug that is required to reach the same degree of inhibition $\left(\mathrm{IC}_{50}\right)$ by itself.

$$
\mathrm{Cl}=\frac{\text { dose of SFN }}{\mathrm{IC}_{50}(\mathrm{SFN})}+\frac{\text { dose of } \mathrm{Ox}}{\mathrm{IC}_{50}(\mathrm{Ox})}
$$

In this equation, the sum of the dose of SFN and the dose of Ox give 50\% inhibition of cell growth. $\mathrm{Cl}<1$ indicates a synergistic effect; $\mathrm{Cl}=1$, additive effect; and $\mathrm{Cl}>1$, antagonistic effect [23].

Determination of ATP level 
Caco-2 cells were grown in 96 well culture dishes $\left(10^{3}\right.$ cells/well) and allowed to grow overnight. Cell Viability Assay Kit (ApoSENSOR ${ }^{\mathrm{TM}}$, BioVision, CA, USA) was used according to the manufacturer's instructions following a $6 \mathrm{~h}$ exposure to SFN and Ox alone and in combination. The assay utilizes luciferase to catalyze the formation of light from ATP and luciferin, and the light can be measured using a luminometer. Changes in ATP levels were determined by comparing the results with the levels of untreated cells (control).

Annexin-V FITC/PI double labeled flow cytometry

To discriminate between apoptotic and necrotic cell subpopulations simultaneous staining with Annexin V-FITC and Propidium iodide was performed. Cells inc ubated with SFN and/or Ox drugs for 5 and $24 \mathrm{~h}$ were harvested with accutase for $30 \mathrm{~min}$. After centrifugation, cells were resuspended in $100 \mu \mathrm{L}$ binding buffer mixed with $5 \mu \mathrm{L}$ Annexin V-FITC (ImmunoTools, Friesoythe, Germany) and $5 \mu \mathrm{PI}$ and then incubated in dark for $10 \mathrm{~min}$ at 4 ${ }^{\circ} \mathrm{C}$. Fluorescence was measured with a flow cytometer.

Determination of DNA Fragmentation

Nuclear fragmentation as a late marker of apoptosis was determined by (i) DNA-staining with SYTOX Green, and (ii) quantification of cytoplasmic histone associated DNA fragments. For SYTOX $^{\circledR}$ Green staining, cells $\left(1 \times 10^{6}\right)$ were seeded onto glass slides and incubated in Quadriperm wells with the test compounds for $48 \mathrm{~h}$. Thereafter glass slides were washed with PBS and cells were fixed with $2 \%$ paraformaldehyde. DNA was stained with $0.25 \mu \mathrm{M}$ SYTOX-Green solution (Invitrogen, Karlsruhe, Germany) and then visualized under an epifluorescence microscope (Zeiss Axioskope 2). 
The Cell Death Detection ELIS A ${ }^{\text {PLUS }}$ method was used to quantify apoptotic cell death in the cellular system by measuring cytoplasmic histone associated DNA fragments. Cytoplasmic histone associated DNA fragments in control and treated cells were quantified using a commercially available ELIS A kit (Roche Diagnostics). Briefly, Caco-2 cells were grown in 96 well culture dishes $\left(10^{3}\right.$ cells/well) and allowed to grow overnight. The cells were then incubated with or without (control) the test substances. After $24 \mathrm{~h}$ of treatment, the cells were centrifuged with $200 \mathrm{xg}$ for $10 \mathrm{~min}$ and the supernatant containing DNA from necrotic cells was removed. The cell pellet was resuspended in $200 \mu$ Lysis Buffer and incubated for $30 \mathrm{~min}$ followed by centrifugation at $200 \mathrm{x}$ g for $10 \mathrm{~min}$. Then $20 \mu \mathrm{l}$ of the supernatant were transferred to streptavidin-coated wells in a mircotiter plate. The supernatant aliquots were incubated for $2 \mathrm{~h}$ at room temperature with $80 \mu \mathrm{l}$ of an immunoreagent containing monoclonal antibodies against histone (biotinlabeled) and DNA (peroxidase-conjugated), with which the nucleosomes in the supernatant bind. The immobilized antibody-histone complexes were washed three times with incubation buffer to remove cell components that were not immunoreactive. Then $100 \mu \mathrm{l}$ ABTS solution was added to each well and the plates were incubated at room temperature on a plate shaker at $250 \mathrm{rpm}$ for $20 \mathrm{~min}$. Finally, the amount of colored product and thus of the immobilized antibody-histone complexes (DNA fragments) in the plate was measured spectrophotometrically at $405 \mathrm{~nm}$ on a microplate spectrophotometer (Fluostar Optima, BMG Labtech, Durham, NC) using ABTS solution as a blank control.

Mitochondrial membrane potential $\left(\Delta \Psi_{\mathrm{m}}\right)$ analysis

Cell cultures were seeded into cultivation flasks at a densitiy of $1 \times 10^{5}$ cells/well and allowed to grow overnight. Cells were stained with JC-1, as a component of the JC-1 Mitochondrial membrane potential Assay Kit (Cayman Chemical Company, Ann Harbor, MI) following a 6 $\mathrm{h}$ and $24 \mathrm{~h}$ exposure to SFN and Ox alone and in combination. JC-1 is a lipophilic, cationic 
dye that can selectively enter into mitochondria and reversibly change color from green to red as the membrane potential increases. Changes in $\Delta \Psi_{\mathrm{m}}$ were finally assessed by microfluorimetry analysis using TECAN SpectraFluor Plus (TECAN Austria GmbH, Grödig, Austria) and indicated as changes of red/green ratio.

Caspase- 3 activity Assay

Caco-2 cells were seeded in $80 \mathrm{~cm}^{2}$ flasks, allowed to grown overnight. Caspase- 3 activity was analyzed using a fluorometric immunosorbent enzyme assay (Roche Diagnostics) according to the manufacturer's instructions. Briefly, after $24 \mathrm{~h}$ of incubation with the test substances, the cells were incubated with lysis buffer for $10 \mathrm{~min}$. After cell lysis and following centrifugation, samples were removed and transferred to the anti-caspase 3-coated well of a microplate, capturing caspase-3. After $1 \mathrm{~h}$, the immobilized antibody-caspase 3 complexes were washed three times to remove cell components that are not immunoreactive. Afterwards, samples were incubated with caspase substrate (Ac-DEVD-AFC) for $120 \mathrm{~min}$ that is proteolytically cleaved into free fluorescent AFC. Then the AFC can be measured fluorometrically at excitation $430 \mathrm{~nm}$ and emission $535 \mathrm{~nm}$. Finally, protein concentrations were measured and adapted to the activity.

SDS-polyacrylamide gel electrophoresis and immunoblot analysis

Caco-2 cells were seeded in $80 \mathrm{~cm}^{2}$ flasks; $24 \mathrm{~h}$ after plating, cells were incubated with substances for 6 hours. After washing the cells for three times with ice-cold PBS, followed by an incubation step with cell lysis buffer (Cell signalling, Berverly, MA) containing multiple protease inhibitors (Complete Mini ${ }^{\circledR}$, Roche) for 20 min at $4{ }^{\circ} \mathrm{C}$, cells were harvested by scraping. Protein extracts were obtained after sonication of cell lysates ( 2 x 5 s) and 
centrifuged at $10.000 \mathrm{rpm}$ for $10 \mathrm{~min}$ at $4{ }^{\circ} \mathrm{C}$. Samples were analyzed for their protein content using the BioRad $^{\circledR}$ colorimetric assay according to the method of Bradford (BioRad Laboratories). After addition of sample buffer (Roti Load ${ }^{\circledR}$, Roth, Karlsruhe, Germany) to the total cellular extract and boiling for $5 \mathrm{~min}$ at $95^{\circ} \mathrm{C}, 30-40 \mu \mathrm{g}$ of total protein lysate was separated on a $10 \%$ or $12 \%$ SDS-polyacrylamide gel. Protein was transferred onto nitrocellulose membrane (Schleicher\&Schuell, Dassel, Germany) and the membrane was blocked for one hour at room temperature with $5 \%$ skimmed milk in Tris-buffered saline containing $0.05 \%$ Tween 20 (TBS-T). Next, blots were washed and incubated overnight at 4 ${ }^{\circ} \mathrm{C}$ in TBS-T containing either $5 \%$ bovine serum albuminate (BSA) or $5 \%$ skimmed milk with a 1:1000 or 1:2000 dilution of primary antibodies for PARP, full length as well cleaved Caspase-8 (all from Cell Signaling, Berverly, MA) and TRAIL (from Santa Cruz Biotechnology, Heidelberg, Germany). The secondary, horseradish peroxidase-conjugated, antibody (Santa Cruz Biotechnology) was diluted at 1:2000 or 1:4000 and incubated with the membrane for another $60 \mathrm{~min}$ in skimmed milk. After chemoluminescence reaction (ECL, Amersham pharmacia biotech, Wien, Austria), bands were detected after exposure to Hyperfilm-MP (Amersham International plc, Buckinghamshire, United Kingdom). Blots were reprobed with $\beta$-actin antibody (Santa Cruz Biotechnologies).

\section{Cytotoxicity}

Cytotoxicity was analyzed by measuring lactate dehydrogenase (LDH) release using a commercially available kit (Cytotoxicity detection kit (LDH), Roche). For this, HFF were incubated with SFN and/or Ox for 24 h. Triton X-100 (2\%) was used as a positive control. After centrifugation at $250 \mathrm{x} \mathrm{g}$ for $10 \mathrm{~min}$, the supernatant was carefully removed and transferred into corresponding wells of an optically clear 96-well flat bottom microplate. To determine the LDH activity in the se supernatants, $100 \mu \mathrm{l}$ Reaction mixture was added and the 
samples were incubated for up to $30 \mathrm{~min}$. Finally, the absorbance of the samples was measured at $490 \mathrm{~nm}$.

Statistics

The data are expressed as means \pm SE of at least three independent experiments. Results were analyzed using GraphPad Prism 4.01 (San Diego, CA, USA) by a two way ANOVA. A p value $<0.05$ was considered to be significant.

\section{Results}

Effects of single-drug exposure on cell proliferation of Caco- 2 cells

Effects of SFN $[1-50 \mu \mathrm{M}]$ and $\mathrm{Ox}[100 \mathrm{nM}-10 \mu \mathrm{M}]$ on Caco-2-cell proliferation were assessed after $24 \mathrm{~h}$ of drug exposure (Fig. 1 A-B). Both substances significantly inhibit proliferation in Caco- 2 cells in a dose-dependent manner $(* \mathrm{p}<0.5, * * \mathrm{p}<0.01, * * * \mathrm{p}<0.001$ vs. control). The $\mathrm{IC}_{50} \mathrm{~S}$ for $\mathrm{SFN}$ and $\mathrm{Ox}$ in Caco-2 cells were $26.35 \mu \mathrm{M}$ and $5.58 \mu \mathrm{M}$ respectively.

Synergistic antiproliferative effects of SFN and Ox

For studying combination effects, the cells were exposed to both SFN and Ox simultaneously for $24 \mathrm{~h}$. As shown in Fig. 1C, co-treatment of the cells significantly reduced the $\mathrm{IC}_{50}$ values of the single drugs. The obtained data were analyzed by the CI method of Chou and Talalay [22]. In Caco-2 cells (A), we calculated a CI of 0.3, which ind icates synergism (see "Material and Methods"). 
Effects of SFN/Ox on different apoptotic events

ATP/ADP ratio: Changes in the intracellular ATP/ADP ratio are a useful indicator to distinguish between different modes of cell death and viability. Although, decreasing ATP and increasing ADP levels are generally found in apoptotic cells, cells will rather undergo necrosis when intracellular ATP levels fall below a critical threshold [24]. For a rapid screening of cell death we therefore treated Caco- 2 cells for 1-24 h with SFN [10-20 $\mu \mathrm{M}]$ and Ox [500 nM] alone and in combination and measured effects on the ATP/ADP ratio. As can be seen from Fig. 2A, incubation with SFN and Ox resulted in a significant time- and, at least after $6 \mathrm{~h}$, also dose-dependent reduction of intracellular ATP which reaches a maximum after $24 \mathrm{~h}(* * * \mathrm{p}<0.001)$. As a positive control, we used staurosporine $[0.5 \mu \mathrm{g} / \mathrm{ml}$ ], a well-known inducer of apoptosis [25].

DNA Fragmentation: As DNA cleavage is another hallmark for apoptosis, we further quantified histone-complexed DNA fragments in Caco-2 after $24 \mathrm{~h}$ of treatment. SFN $[20 \mu \mathrm{M}]$, in contrast to $\mathrm{Ox}[500 \mathrm{nM}]$, thereby leads to a significant increase of cystoplasmic histone associated DNA fragments, an effect which could be further enhanced, when the drugs were used in combination (Fig. 2B) $(* * * \mathrm{p}<0.001)$.

Caspase-3-Activity: The activity of the effector caspase-3 was significantly activated $24 \mathrm{~h}$ after stimulation with SFN $[20 \mu \mathrm{M}]$ and Ox [500 nM], respectively, but this effects were not very prominent when compared to the positive control staurosporine. However, SFN could significantly enhance the Ox-induced effects (Fig. 2C) $(* * * \mathrm{p}<0.001)$, which is in agreement with the observed cleavage of PARP (Fig. 2D) $(* * * \mathrm{p}<0.001)$, a clas sical substrate for activated caspase-3. Proteolysis of PARP usually is an indicator for early apoptotic events.

Extrinsic and intrinsic apoptotic events: In the next step, we measured protein levels of the TNF-related apoptosis-inducing ligand (TRAIL) as well as of full length and cleaved caspase-8, both markers of the extrinsic or death receptor-mediated apoptotic pathway. In 
some tumor cell lines, TRAIL protein expression could be induced by chemopreventive agents resulting in TRAIL-mediated apoptosis in an autocrine or paracrine manner $[26 ; 27$; 28]. This suggests that induction of endogenously expressed TRAIL after SFN/Ox-treatment for $6 \mathrm{~h}$ (Fig. 3A) may further enhance their therapeutic outcome. Additionally, co-stimulation resulted in a decrease of procaspase- 8 and an increase of cleaved caspase- 8 after $6 \mathrm{~h}$ of treatment, a common upstream event of caspase-3 activation (Fig. 3B).

Next, we determined whether both agents might also increase mitochondrial membrane depolarization as a consequence of the activation of the intrinsic apoptotic pathway. For this, cells were incubated with SFN $[20 \mu \mathrm{M}]$ and $\mathrm{Ox}[500 \mathrm{nM}]$ alone and in combination for 6 and $24 \mathrm{~h}$ before staining with JC-1 (Fig. 3C). JC-1 is a mitochondrialselective dye and forms aggregates in normal polarized mitochondria that result in a green orange emission of $590 \mathrm{~nm}$ after excitation at $490 \mathrm{~nm}$. Upon depolarization of the mitochondrial membrane, JC-1 forms monomers that emit only green fluorescence at $527 \mathrm{~nm}$. As shown in Fig. 3C, SFN induced a depolarization of the mitochondrial membrane potential, which was significant after $24 \mathrm{~h}$ of treatment. In contrast to SFN, Ox-treatment did not show any detectable effects, neither after $6 \mathrm{~h}$ nor $24 \mathrm{~h}$ of incubation. However, combinatorial treatment resulted in a distinct decrease of the red-green fluorescence intensity ratio after $6 \mathrm{~h}$ $(* * \mathrm{p}<0.01)$ and $24 \mathrm{~h}(* * * \mathrm{p}<0.001)$. These observations pointed towards involvement of both extrinsic and intrinsic apoptotic pathways in SFN/Ox-mediated induction of apoptosis.

Switching from apoptosis to necrosis with increasing concentrations of SFN/O x

Even though increasing concentrations of Ox/SFN [e.g. $1 \mu \mathrm{M} / 20 \mu \mathrm{M}$ ] can further potentiate the observed effects on cell growth inhibition shown in Fig. 1 (data not presented here), these effects seem not to be explainable by enhanced induction of apoptosis, as DNAfragmentation for example could not be further amplified with increasing concentrations of 
oxaliplatin (Fig. 2B), indicating other modes of action. Thus, to discriminate between different modes of cell death, Caco-2 cells treated with SFN $[20 \mu \mathrm{M}], \mathrm{Ox}[500 \mathrm{nM}-1 \mu \mathrm{M}]$ alone and in combination for 5 and $24 \mathrm{~h}$, were analyzed by Annexin V-FITC/PI labelling and flow cytometry. The degree of apoptosis thereby was quantitatively expressed as a percentage of the Annexin V-FITC-positive but PI-negative cells, while necrosis or late apoptosis was quantitatively expressed as a percentage of PI-positive or Annexin V-FITC/PI double-stained cells. Analysis after $5 \mathrm{~h}$ was chosen in order to differentiate between primary and secondary necrosis as a result of late apoptosis. Interestingly at this time point, Annexin V-FITC positive but also PI-positive cells could be measured indicating direct necrotizing effects of SFN and Ox (Fig. 4A-B). Compared to the 5 h-treatment, the population of apoptotic cells in untreated and SFN $[20 \mu \mathrm{M}]$ as well as Ox [500 nM-1 $\mu \mathrm{M}]$-treated Caco-2 cells (Fig. 4C-D) seems to decline after $24 \mathrm{~h}$. However, the rate of apoptosis was still significantly induced in the cotreated cells, but again this effect could not be further increased with a higher concentration of Ox $[1 \mu \mathrm{M}]$. Rather, at this concentration, a distinct population of PI-stained cells could be observed, whereas a mixture of cells undergoing rapid primary as well as secondary necrosis/late apoptosis can be assumed (Fig. 4B). Obviously, apoptotic effects seem to reach a maximum after $5 \mathrm{~h}$ of treatment, which is replaced by a shift towards an increased population of necrotic cells after $24 \mathrm{~h}$.

These observations could also be confirmed by SYTOX Green staining (Fig. 5) which was used to analyze late apoptosis. SYTOX Green nucleic acid stain is an unsymmetrical cyanine dye with three positive charges that is completely excluded from live eukaryotic and prokaryotic cells. Binding of SYTOX Green stain to nucleic acids of Caco-2- cells incubated with SFN $[20 \mu \mathrm{M}]$ and Ox [500nM], clearly presents signs of apoptotic events indicated by cell shrinkage, chromatin condensation and the formation of apoptotic bodies (see white arrows in Fig. 5A and C). However, again with increasing concentrations of $\mathrm{Ox}[1 \mu \mathrm{M}]$, 
necrotic alterations like osmotic swelling and cell lysis with loss of membrane integrity became more prominent (Fig. 5C).

Taken together, these observations clearly indicate that depending on the applied concentration and the treatment duration, antiproliferative effects of SFN/Ox against Caco-2 cells can be associated with both apoptotic as well as necrotic events.

Effects of SFN and Ox on cell proliferation and LDH-release of human foreskin fibroblasts (HFF)

To analyze a possible toxicity of SFN and Oxaliplatin on normal tissue cells, human foreskin fibroblasts were treated either with SFN $[10-20 \mu \mathrm{M}]$ and $\mathrm{Ox}[500 \mathrm{nM}-1 \mu \mathrm{M}]$ alone or in combination and cell proliferation as well as LDH-release as a marker of direct cytotoxicity were measured after $24 \mathrm{~h}$ (Fig. 6). Actually, SFN alone was found to significantly inhibit cell growth of HFF in a dose-dependent $(* \mathrm{p}<0.05$; ** $\mathrm{p}<0.01$, *** $\mathrm{p}<0.001)$ (Fig. 6A), but in contrast to Caco-2 cells this effect was not further enhanced and no signs of cytotoxicity could be observed when SFN was combined with oxaliplatin (Fig. 6B). 


\section{Discussion}

Oxaliplatin is now widely used in the treatment of advanced colorectal cancers mostly in combination with continuous intravenous infusions of 5-fluorouracil [3]. However, adverse effects, e.g. acute and persistent neuropathy as well as the development of chemotherapy resistance limit the overall success of oxaliplatin-based treatment regimens. Since several in vitro and in vivo studies show first promising results regarding the chemosensitizing capability of phytochemicals in different cancer models [6], we were interested, whether plant-derived SFN might be able to enhance Ox-induced anti-tumor activities in colorectal cancer cells, also concerning modes of action which might help to overcome drug resistance in cancer tissues.

Most chemotherapeutic agents, including oxaliplatin, and irradiation act primarily by inducing apoptosis, accordingly, defects in the apoptotic pathway often account for chemotherapy resistance in different tumor cells, which could also be demonstrated for drug resistance arising against oxaliplatin in colorectal cancer cells [29]. Novel targeted therapies that more potently induce cell death in cancer cells or sensitize them to established cytotoxic agents and radiation by modulating the apoptotic machinery might therefore not only enhance therapeutic outcome but can further help to reverse chemotherapeutic drug resistance [30].

Our first results quickly revealed SFN-induced potentiation of cell growth inhibition mediated by oxaliplatin, which was more-than-additive as indicated by combination index analysis. In addition, these effects were accompanied by different hallmarks of apoptosis, such as reduced ATP levels, Caspase-3-activation, PARP cleavage and DNA Fragmentation. Further experiments could demonstrate that thereby apparently both, extrinsic and intrinsic apoptotic pathways were involved, as indicated by caspase-8-cleavage and increased mitochondrial membrane permeabilization. Interestingly, we could also observe an induction of TRAIL protein levels, a member of the TNF family of cytokines, which can induce apoptotic cell 
death in a variety of tumor cells by engaging the death receptors DR4 and DR5, while sparing most normal cells [31]. This might be due to the HDAC inhibitory properties of Sulforaphane [8], since several other HDAC inhibitors were also shown to induce expression of TRAIL, DR4 or related proteins, which contributed to subsequent apoptotic events induced by these agents [32]. Since some drugs and radiation sensitize tumor cells to TRAIL-induced cell death, several studies have expectedly shown that combinations of recombinant TRAIL and some chemotherapeutic drugs exhibit synergistic effects in inducing tumor cell apoptosis in vitro and in vivo $[33 ; 34]$. Whether endogenously induced TRAIL possibly acts in a similar way remains to be elucidated. Another interesting aspect is that TRAIL, in contrast to DNAdamaging chemotherapeutic drugs or radiation, induces apoptosis independently of p53 [31], which might be helpful to circumvent resistance to conventional chemotherapy and radiotherapy. However, in contrast to known apoptosis inducers, such as staurosporin, apoptotic events induced by SFN and Ox were not very prominent and may only partly account for the observed inhibition of cell proliferation.

In fact, with increasing concentrations of oxaliplatin and increasing treatment duration, annexin- $\mathrm{V}$ and PI-staining revealed a shift from an apoptotic towards a distinct population of necrotic cells (Fig. 4). Similar results were observed in Sytox Green-stained cells, which showed considerable signs for necrosis like swelling of the organelles or cell lysis with loss of membrane integrity (Fig. 5). This is consistent with the almost complete ATP depletion after 24 h of incubation, which may further account for the low apoptotic response [35].

Currently, the majority of clinical chemotherapeutic agents ultimately induce tumor cell apoptosis following treatment, however, noting the facts that many cancers have defective apoptosis machinery or aquire apoptosis resistance during therapy [36], or the finding, that apoptosis may be reversed in cancer cells [37], it is reasonable to consider whether activating alternative cell death pathways, such as necrosis, may be another effective strategy for cancer therapy [38]. Unlike apoptosis which is largely immune silent or immunosuppressive, 
therapy-induced necrotic cell death initiates an immune response to tumor cells [39]. This inflammatory response may help to recruit cytotoxic immune cells to the tumor site, thereby increasing the efficacy of the chemotherapeutic drugs. However, conversely the proinflammatory conditions might also damage normal tissue or induce the production of mitogenic or prosurvival cytokines, which can activate signalling pathways that promote cell excrescence in the damaged area and might induce tumor cell migration and metastasis [40; 41]. Further studies are therefore required to address the question whether the inflammation associated with necrosis might be desirable in the context of cancer treatment or rather leads to further tumor growth or even overshooting inflammation, leading to autoimmunity. Interestingly, Ingenol-3-angelate, another plant-derived compound, was recently shown to mediate its in vitro anticancer activities via the induction of primary necrosis [42; 43], as displayed by plasma membrane and mitochondrial disruption leading to the activation of an antitumor immune response [44]. Thus, the success of Ingenol-3-angelate in phase IIa clinical trials against human skin cancer might again support the importance and potential of cytotoxic agents that act through irreversible necrotic cell death. [45]. In healthy human fibroblasts, SFN was found to inhibit cell growth in a dose-dependent manner, an effect which was already reported for other HDAC inhibitors [46; 47]. But in contrast to Caco-2 cells, growth inhibitory effects on fibroblasts were not further enhanced and no signs of cytotoxicity could be observed when SFN was combined with oxaliplatin, indicating a selective toxicity towards the tumor cell line while inducing only growth arrest in normal fibroblasts.

Summarizing our findings, we could demonstrate for the first time that the secondary plant-metabolite sulforaphane is capable of amplifying Ox-induced cell growth inhibition in colon cancer cells supposedly via induction of different modes of cell death. Sulforaphane might thereby not only be a promising candidate due to it's potent chemopreventive properties, but also pharmacokinetic studies in both rats and humans indicate, that dietary absorbed SFN can be distributed in the body, reach $\mu \mathrm{M}$ levels in the blood and is capable of 
reaching target tissues in an active form, which further supports the clinical relevance of the substance [48; 49]. However, further experiments focusing intramolecular mechanisms together with in vivo animal studies and clinical trials are needed for eventually translating the concept of phytochemicals in combination therapies of human colorectal cancer into clinical applications.

\section{Acknowledge ments}

This work was supported by a graduate scholarship grant from the DFG to Bettina M. Kaminski. Bettina M. Kaminski is a member of the Frankfurt International Research Graduate School for Translational Biomedicine (FIRST), Frankfurt am Main. 


\section{Reference list}

[1]A. Jemal, R. Siegel, E. Ward, Y. Hao, J. Xu, T. Murray, M.J. Thun, Cancer statistics, 2008. CA Cancer J Clin 58 (2008) 71-96.

[2]E. Raymond, S. Faivre, S. Chaney, J. Woynarowski, E. Cvitkovic, Cellular and molecular pharmacology of oxaliplatin. Mol Cancer Ther 1 (2002) 227-235.

[3]J. Capdevila, E. Elez, S. Peralta, T. Macarulla, F.J. Ramos, J. Tabernero, Oxaliplatin-based chemotherapy in the management of colorectal cancer. Expert Rev Anticancer Ther 8 (2008) 1223-1236.

[4]O. Rixe, W. Ortuzar, M. Alvarez, R. Parker, E. Reed, K. Paull, T. Fojo, Oxaliplatin, tetraplatin, cisplatin, and carboplatin: spectrum of activity in drug-resistant cell lines and in the cell lines of the National Cancer Institute's Anticancer Drug Screen panel. Biochem Pharmacol 52 (1996) 1855-1865.

[5]M.A. Graham, G.F. Lockwood, D. Greenslade, S. Brienza, M. Bayssas, E. Gamelin, Clinical pharmacokinetics of oxaliplatin: a critical review. Clin Cancer Res 6 (2000) 1205-1218.

[6]F.H. Sarkar, Y. Li, Using chemopreventive agents to enhance the efficacy of cancer therapy. Cancer Res 66 (2006) 3347-3350.

[7]N. Juge, R.F. Mithen, M. Traka, Molecular basis for chemoprevention by sulforaphane: a comprehensive review. Cell Mol Life Sci 64 (2007) 1105-1127.

[8]M.C. Myzak, P.A. Karplus, F.L. Chung, R.H. Dashwood, A novel mechanism of chemoprotection by sulforaphane: inhibition of histone deacetylase. Cancer Res 64 (2004) 5767-5774.

[9]W.K. Kelly, P.A. Marks, Drug insight: Histone deacetylase inhibitors--development of the new targeted anticancer agent suberoylanilide hydroxamic acid. Nat $\mathrm{Clin}$ Pract Oncol 2 (2005) 150-157.

[10]R.K. Lindemann, B. Gabrielli, R.W. Johnstone, Histone-deacetylase inhibitors for the treatment of cancer. Cell Cycle 3 (2004) 779-788.

[11]M. Grunstein, Histone acetylation in chromatin structure and transcription. Nature 389 (1997) 349-352.

[12]F. McLaughlin, N.B. La Thangue, Histone deacetylase inhibitors open new doors in cancer therapy. Biochem Pharmacol 68 (2004) 1139-1144.

[13]C. Fimognari, M. Nusse, R. Cesari, R. Iori, G. Cantelli-Forti, P. Hrelia, Growth inhibition, cell-cycle arrest and apoptosis in human T-cell leukemia by the isothiocyanate sulforaphane. Carcinogenesis 23 (2002) 581-586.

[14]L. Gamet-Payrastre, P. Li, S. Lumeau, G. Cassar, M.A. Dupont, S. Chevolleau, N. Gasc, J. Tulliez, F. Terce, Sulforaphane, a naturally occurring isothiocyanate, induces cell cycle arrest and apoptosis in HT29 human colon cancer cells. Cancer Res 60 (2000) 1426-1433.

[15]J.F. Kerr, A.H. Wyllie, A.R. Currie, Apoptosis: a basic biological phenomenon with wide-ranging implications in tissue kinetics. Br J Cancer 26 (1972) 239-257.

[16]L. Galluzzi, M.C. Maiuri, I. Vitale, H. Zischka, M. Castedo, L. Zitvogel, G. Kroemer, Cell death modalities: classification and pathophysiological implications. Cell Death Differ 14 (2007) 1237-1243.

[17]R. Khosravi-Far, M.D. Esposti, Death receptor signals to mitochondria. Cancer Biol Ther 3 (2004) 1051-1057.

[18]M.O. Hengartner, The biochemistry of apoptosis. Nature 407 (2000) 770-776.

[19]H. Nakajima, Y.S. Lee, T. Matsuda, N. Mizuta, J. Magae, Different mechanisms for membrane and nuclear damages in apoptosis induced by an immunosuppressant, FTY720. Mol Cells 14 (2002) 332-338. 
[20]X.W. Meng, M.J. Fraser, J.M. Feller, J.B. Ziegler, Caspase-3-dependent and caspase-3independent pathways leading to chromatin DNA fragmentation in HL-60 cells. Apoptosis 5 (2000) 61-67.

[21]R.K. Amaravadi, C.B. Thompson, The roles of therapy-induced autophagy and necrosis in cancer treatment. Clin Cancer Res 13 (2007) 7271-7279.

[22]T.C. Chou, P. Talalay, Quantitative analysis of dose-effect relationships: the combined effects of multiple drugs or enzyme inhibitors. Adv Enzyme Regul 22 (1984) 27-55.

[23]S. Carnesecchi, K. Langley, F. Exinger, F. Gosse, F. Raul, Geraniol, a component of plant essential oils, sensitizes human colonic cancer cells to 5-Fluorouracil treatment. J Pharmacol Exp Ther 301 (2002) 625-630.

[24]Y. Eguchi, S. Shimizu, Y. Tsujimoto, Intracellular ATP levels determine cell death fate by apoptosis or necrosis. Cancer Res 57 (1997) 1835-1840.

[25]X.Q. Wang, A.Y. Xiao, C. Sheline, K. Hyrc, A. Yang, M.P. Goldberg, D.W. Choi, S.P. $\mathrm{Yu}$, Apoptotic insults impair $\mathrm{Na}+, \mathrm{K}+-\mathrm{ATPase}$ activity as a mechanism of neuronal death mediated by concurrent ATP deficiency and oxidant stress. J Cell Sci 116 (2003) 2099-2110.

[26]L. Altucci, A. Rossin, W. Raffelsberger, A. Reitmair, C. Chomienne, H. Gronemeyer, Retinoic acid-induced apoptosis in leukemia cells is mediated by paracrine action of tumor-selective death ligand TRAIL. Nat Med 7 (2001) 680-686.

[27]Q. Chen, B. Gong, A.S. Mahmoud-Ahmed, A. Zhou, E.D. Hsi, M. Hussein, A. Almasan, Apo2L/TRAIL and Bcl-2-related proteins regulate type I interferon-induced apoptosis in multiple myeloma. Blood 98 (2001) 2183-2192.

[28]K. Oshima, N. Yanase, C. Ibukiyama, A. Yamashina, N. Kayagaki, H. Yagita, J. Mizuguchi, Involvement of TRAILTRAIL-R interaction in IFN-alpha-induced apoptosis of Daudi B lymphoma cells. Cytokine 14 (2001) 193-201.

[29]I. Gourdier, M. Del Rio, L. Crabbe, L. Candeil, V. Copois, M. Ychou, C. Auffray, P. Martineau, N. Mechti, Y. Pommier, B. Pau, Drug specific resistance to oxaliplatin is associated with apoptosis defect in a cellular model of colon carcinoma. FEBS Lett 529 (2002) 232-236.

[30]P. Gimenez-Bonafe, A. Tortosa, R. Perez-Tomas, Overcoming drug resistance by enhancing apoptosis of tumor cells. Curr Cancer Drug Targets 9 (2009) 320-340.

[31]H. Yagita, K. Takeda, Y. Hayakawa, M.J. Smyth, K. Okumura, TRAIL and its receptors as targets for cancer therapy. Cancer Sci 95 (2004) 777-783.

[32]A. Insinga, S. Monestiroli, S. Ronzoni, V. Gelmetti, F. Marchesi, A. Viale, L. Altucci, C. Nervi, S. Minucci, P.G. Pelicci, Inhibitors of histone deacetylases induce tumorselective apoptosis through activation of the death receptor pathway. Nat Med 11 (2005) 71-76.

[33]S. Shankar, R.K. Srivastava, Enhancement of therapeutic potential of TRAIL by cancer chemotherapy and irradiation: mechanisms and clinical implications. Drug Resist Updat 7 (2004) 139-156.

[34]H. Wajant, K. Pfizenmaier, P. Scheurich, TNF-related apoptosis inducing ligand (TRAIL) and its receptors in tumor surveillance and cancer therapy. Apoptosis 7 (2002) 449459.

[35]Y. Tsujimoto, Apoptosis and necrosis: intracellular ATP level as a determinant for cell death modes. Cell Death Differ 4 (1997) 429-434.

[36]F.H. Igney, P.H. Krammer, Death and anti-death: tumour resistance to apoptosis. Nat Rev Cancer 2 (2002) 277-288.

[37]H.L. Tang, K.L. Yuen, H.M. Tang, M.C. Fung, Reversibility of apoptos is in cancer cells. Br J Cancer 100 (2009) 118-122.

[38]M.S. Ricci, W.X. Zong, Chemotherapeutic approaches for targeting cell death pathways. Oncologist 11 (2006) 342-357. 
[39]J. Savill, V. Fadok, Corpse clearance defines the meaning of cell death. Nature 407 (2000) 784-788.

[40]M.T. Lotze, K.J. Tracey, High-mobility group box 1 protein (HMGB1): nuclear weapon in the immune arsenal. Nat Rev Immunol 5 (2005) 331-342.

[41]Z. Zhou, Y. Yamamoto, F. Sugai, K. Yoshida, Y. Kishima, H. Sumi, H. Nakamura, S. Sakoda, Hepatoma-derived growth factor is a neurotrophic factor harbored in the nucleus. J Biol Chem 279 (2004) 27320-27326.

[42]S.K. Gillespie, X.D. Zhang, P. Hersey, Ingenol 3-angelate induces dual modes of cell death and differentially regulates tumor necrosis factor-related apoptosis-inducing ligand-ind uced apoptosis in melanoma cells. Mol Cancer Ther 3 (2004) 1651-1658.

[43]S.M. Ogbourne, A. Suhrbier, B. Jones, S.J. Cozzi, G.M. Boyle, M. Morris, D. McAlpine, J. Johns, T.M. Scott, K.P. Sutherland, J.M. Gardner, T.T. Le, A. Lenarczyk, J.H. Aylward, P.G. Parsons, Antitumor activity of 3-ingenyl angelate: plasma membrane and mitochondrial disruption and necrotic cell death. Cancer Res 64 (2004) 28332839.

[44]J.M. Challacombe, A. Suhrbier, P.G. Parsons, B. Jones, P. Hampson, D. Kavanagh, G. E. Rainger, M. Morris, J.M. Lord, T.T. Le, D. Hoang-Le, S.M. Ogbourne, Neutrophils are a key component of the antitumor efficacy of topical chemotherapy with ingenol3-angelate. J Immunol 177 (2006) 8123-8132.

[45]G. Siller, K. Gebauer, P. Welburn, J. Katsamas, S.M. Ogbourne, PEP005 (ingenol mebutate) gel, a novel agent for the treatment of actinic keratosis: results of a randomized, double-blind, vehicle-controlled, multicentre, phase IIa study. Australas J Dermatol 50 (2009) 16-22.

[46]P. Atadja, L. Gao, P. Kwon, N. Trogani, H. Walker, M. Hsu, L. Yeleswarapu, N. Chandramouli, L. Perez, R. Versace, A. Wu, L. Sambucetti, P. Lassota, D. Cohen, K. Bair, A. Wood, S. Remiszewski, Selective growth inhibition of tumor cells by a novel histone deacetylase inhibitor, NVP-LAQ824. Cancer Res 64 (2004) 689-695.

[47]P. Atadja, M. Hsu, P. Kwon, N. Trogani, K. Bhalla, S. Remiszewski, Molecular and cellular basis for the anti-proliferative effects of the HDAC inhibitor LAQ824. Novartis Found Symp 259 (2004) 249-266; discussion 266-248, 285-248.

[48]R. Hu, V. Hebbar, B.R. Kim, C. Chen, B. Winnik, B. Buckley, P. Soteropoulos, P. Tolias, R.P. Hart, A.N. Kong, In vivo pharmacokinetics and regulation of gene expression profiles by isothiocyanate sulforaphane in the rat. J Pharmacol Exp Ther 310 (2004) 263-271.

[49]L. Ye, A.T. Dinkova-Kostova, K.L. Wade, Y. Zhang, T.A. Shapiro, P. Talalay, Quantitative determination of dithiocarbamates in human plasma, serum, erythrocytes and urine: pharmacokinetics of broccoli sprout isothiocyanates in humans. Clin Chim Acta 316 (2002) 43-53. 


\section{Figure Legends}

Fig. 1 A, B) Inhibition of cell proliferation of Caco-2 by 24 h exposure to SFN and Ox alone. Values represent mean $\pm \mathrm{SE}(\mathrm{n}=8) ; * \mathrm{p}<0.05, * * \mathrm{p}<0.01, * * * \mathrm{p}<0.001$ vs. control. C) The combined effects of concurrent treatment with SFN and Ox on Caco-2 cells. Cell proliferation was mesaured by BrdU incorporation after $24 \mathrm{~h}$ of incubation. CI values were determined by the method of Chou and Talalay [22] described in "Material and Methods". Values represent mean $\pm \operatorname{SE}(\mathrm{n}=3) ; * * \mathrm{p}<0.01, * * * \mathrm{p}<0.001$ vs. control.

Fig. 2 A) Intracellular content of ATP in control (untreated), SFN- and/or Ox- as well as staurosporine $(0.5 \mu \mathrm{g} / \mathrm{ml})$-treated cells. Caco- 2 cells were incubated with the test substances for 1 to $24 \mathrm{~h}$. Results are expressed as the percentage of control. Values represent mean $\pm \mathrm{SE}(\mathrm{n}=4) ; * \mathrm{p}<0.05, * * \mathrm{p}<0.01$, *** $\mathrm{p}<0.001$ vs. control. B) Quantification of cytoplasmic histone associated DNA after $24 \mathrm{~h}$ of incubation with the test compounds. Values represent mean $\pm S E(n=4)$; *** $p<0.001$. C) Effects of SFN, Ox, their combination and staurosporine on activation of caspase-3 in Caco-2 cells after $24 \mathrm{~h}$ of exposure. Results are expressed as the percentage of control. Values represent mean $\pm \mathrm{SE}(\mathrm{n}=4) ; * \mathrm{p}<0.05$, *** $\mathrm{p}<0.001$. D) Western blot analysis for PARP cleavage using whole cell extracts from Caco-2 cells exposed to SFN and Ox, separately or in combination, for $6 \mathrm{~h}$. The bar graph presents densitometric analysis of the Western blot images normalized to $\beta$-actin (mean $\pm \mathrm{SE} ;(\mathrm{n}=3)$; *** $\mathrm{p}<0.001$. Representative immunoblots of three independent experiments are shown.

Fig. 3 A) Western blot analysis for TRAIL in Caco-2 cells after incubation with SFN [20 $\mu \mathrm{M}$ ] and/or Ox [100-500 $\mathrm{nM}$ ] for $6 \mathrm{~h}$. A representative immunoblot of three 
independent experiments is shown. The bar graph presents densitometric analysis of the Western blot images normalized to $\beta$-actin (mean $\pm \mathrm{SE}(\mathrm{n}=3) ; * \mathrm{p}<0.05$, ** $\mathrm{p}<0.01, * * * \mathrm{p}<0.001)$. B) Western blot analysis for caspase-8, full length and cleaved, using whole cell extracts from Caco-2 cells exposed to SFN and/or Ox for $6 \mathrm{~h}$. A representative immunoblot of three independent experiments is shown. The bar graph presents densitometric analysis of the Western blot images normalized to $\beta$-actin $($ mean $\pm \operatorname{SE}(\mathrm{n}=3) ; * \mathrm{p}<0.05, * * * \mathrm{p}<0.001)$. C) Loss of mitochondrial membrane potential $(\Delta \Psi \mathrm{m})$ in Caco-2 cells exposed to SFN and Ox, alone or in combination, after 6 and 24 h of treatment. Results represent mean of at least three experiments, * $\mathrm{p}<0.05, * * \mathrm{p}<0.01, * * * \mathrm{p}<0.001$.

Fig. 4 Effects of SFN and Ox, separately and in combination, on Annexin-V FITC/PI double labeled cells after 5 and $24 \mathrm{~h}$ of incubation. Cells were analysed by flow cytometry as described in „Material and Methods“. The percentage of apoptotic and necrotic (B and D) cells vs. control as a result of the FACS analysis are presented by bar graphs. Values represent mean \pm SE $(n=4)$, quantifying a minimum of 10.000 cells per treatment $(* \mathrm{p}<0.05, * * \mathrm{p}<0.01, * * * \mathrm{p}<0.001)$.

Fig. 5 Sytox Green ${ }^{\circledR}$ staining following a $48 \mathrm{~h}$ exposure to control or the test compounds. Arrows indicate morphological changes as a consequence of SFN/Ox-induced apoptosis. Experiments were repeated three times, and the results were comparable. Data from a representative experiment are shown. The percentage of apoptotic cells (B and D) cells vs. control are presented by bar graphs. Values represent mean $\pm \mathrm{SE}$ $(\mathrm{n}=3), * * * \mathrm{p}<0.001$. 
Fig. 6 A) Effects of SFN and Ox, separately and in combination, on cytotoxicity in HFF after $24 \mathrm{~h}$ of incubation. Results are expressed as the percentage of control. Values represent mean $\pm \operatorname{SE}(\mathrm{n}=4) ; * * * \mathrm{p}<0.001$. B) The combined effects of concurrent treatment with SFN and Ox on HFF cells. Cell proliferation was mesaured by BrdU incorporation after $24 \mathrm{~h}$ of incubation. Values represent mean $\pm \operatorname{SE}(n=4) ; * p<0.05$, $* * \mathrm{p}<0.01, * * * \mathrm{p}<0.001$ vs. control.
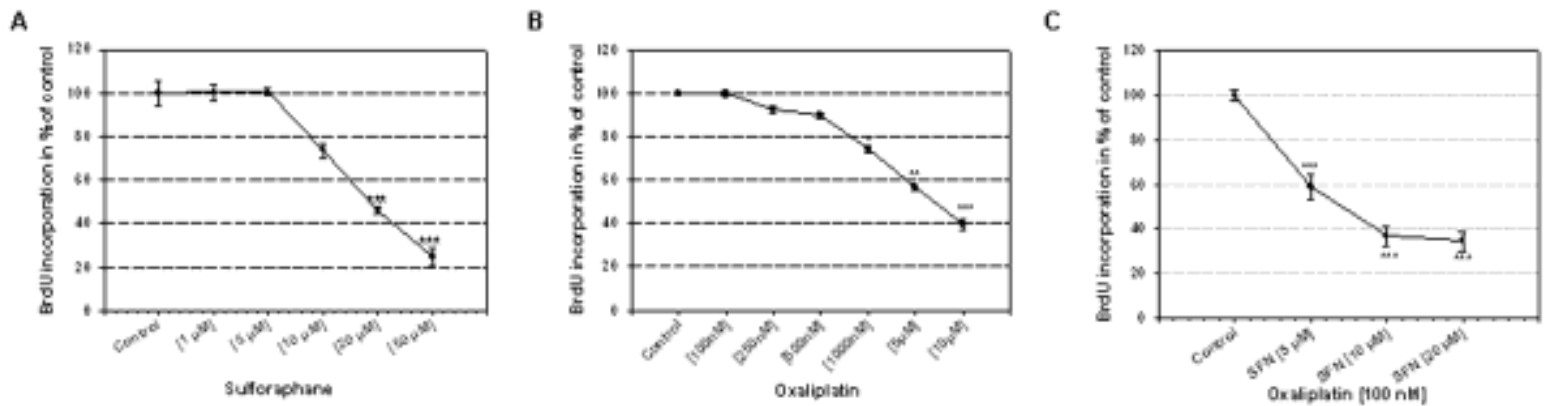
A

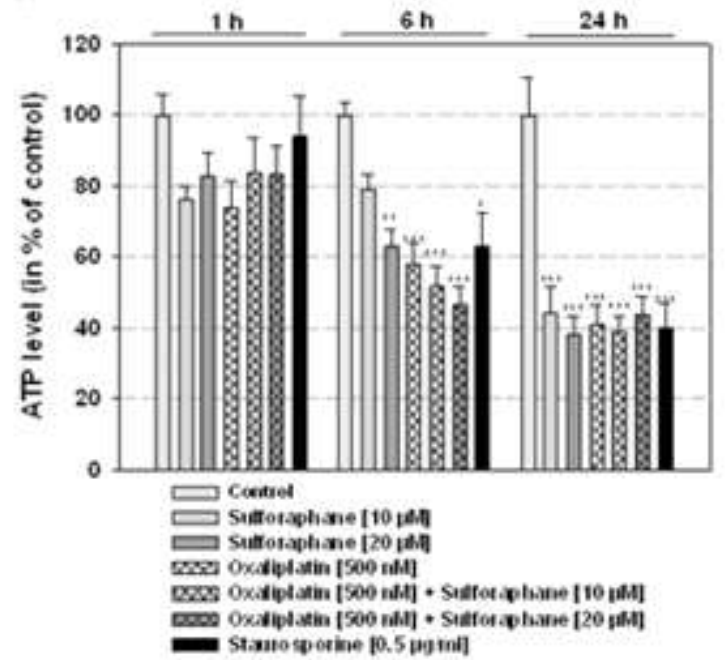

C

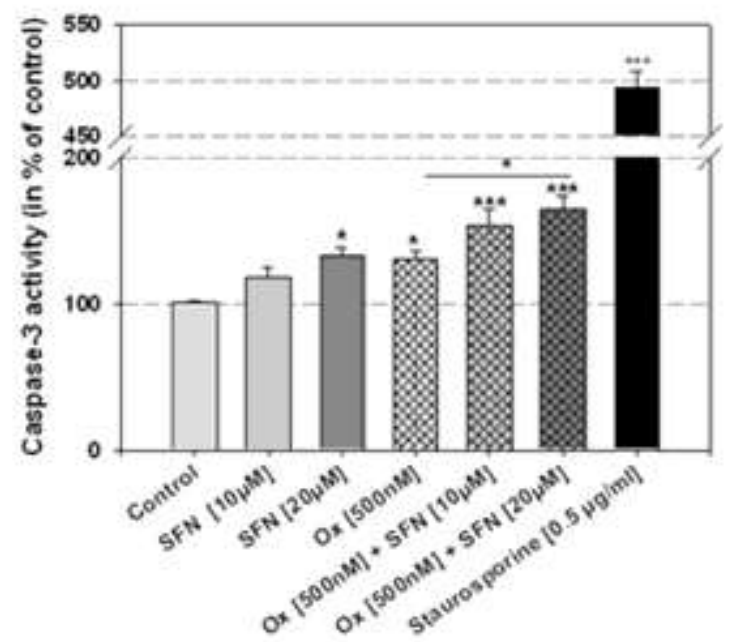

B

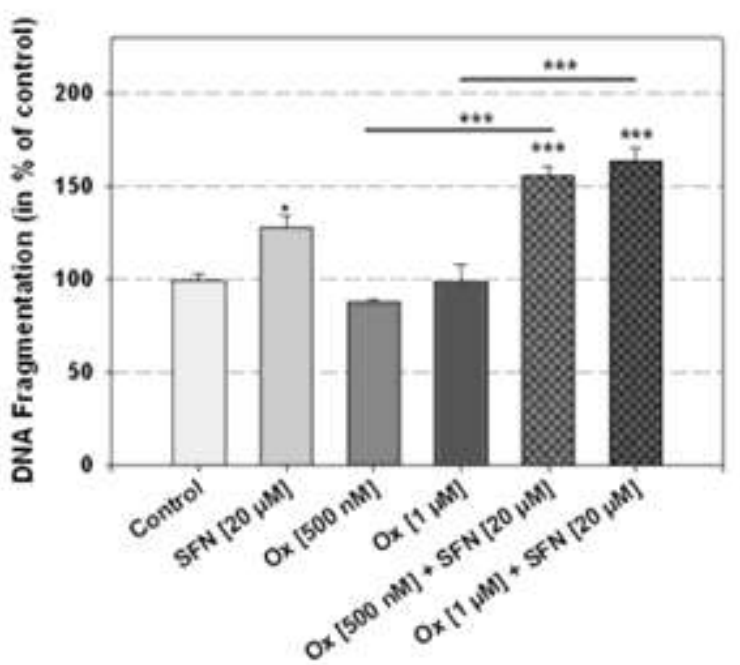

D

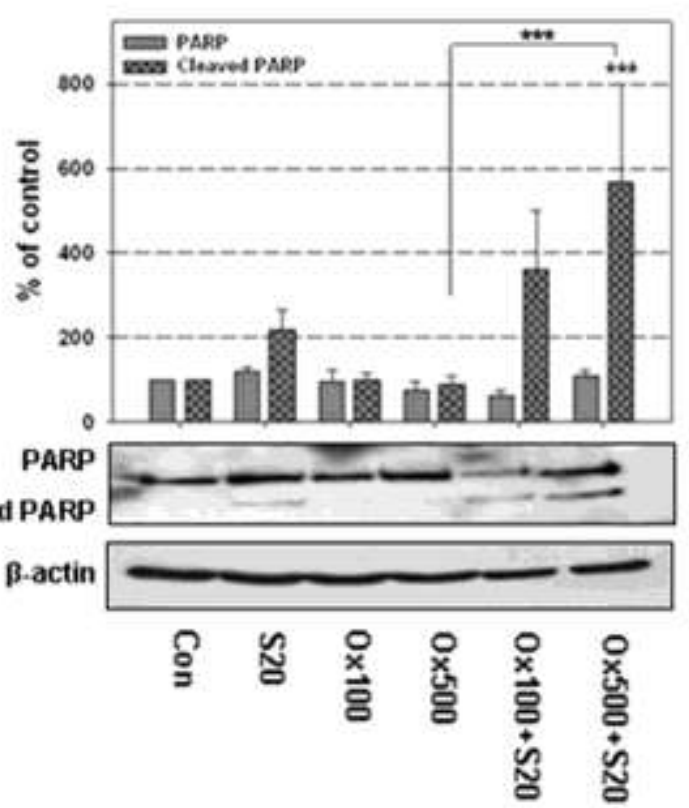

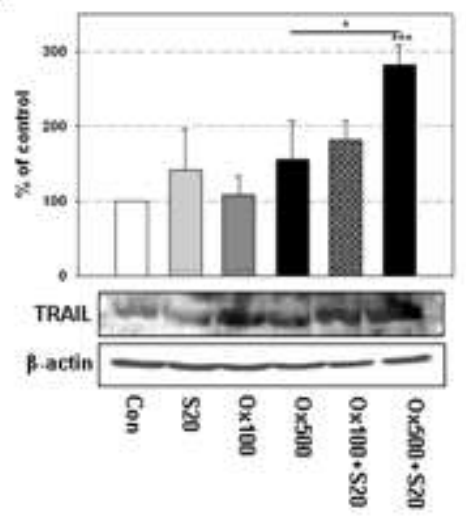

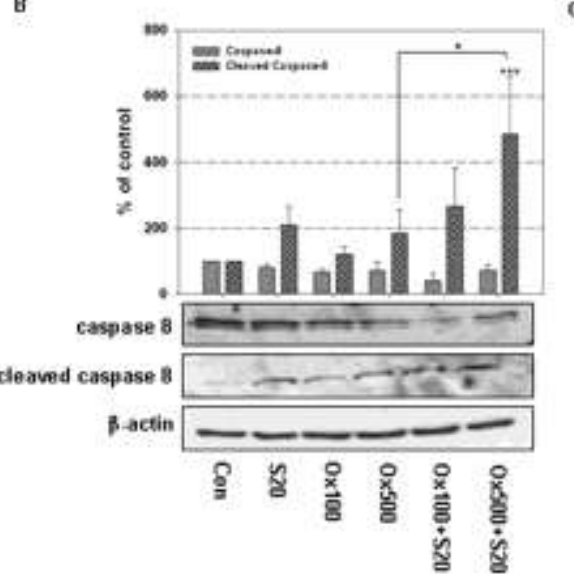

c

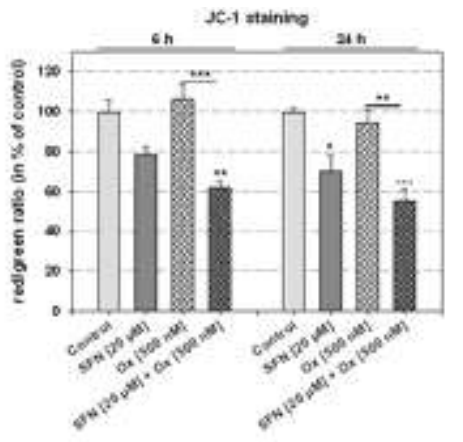


A
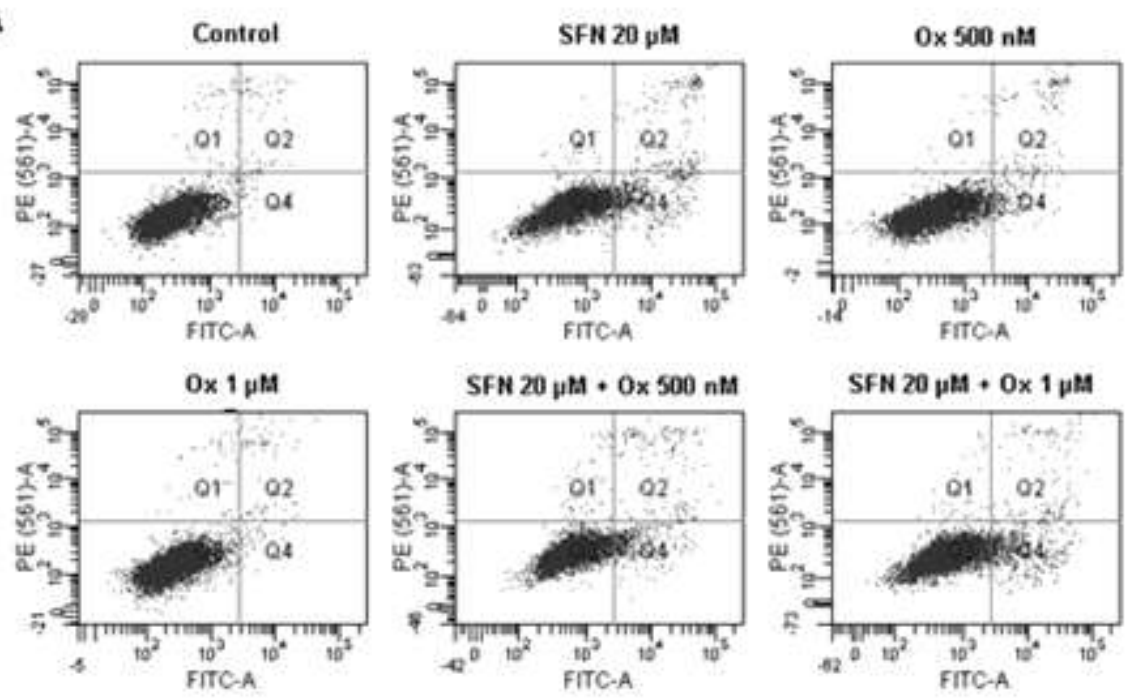

B
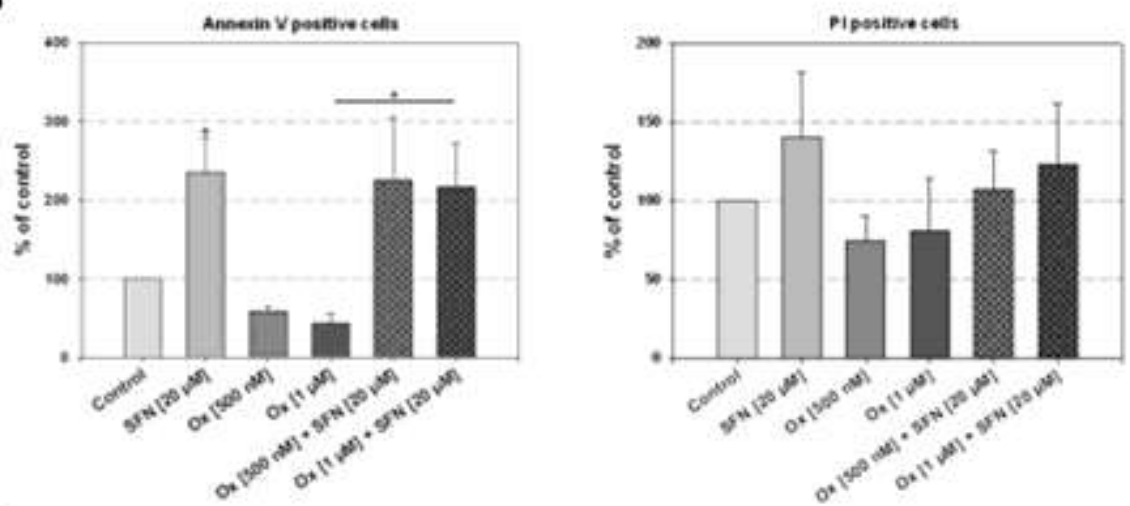

C
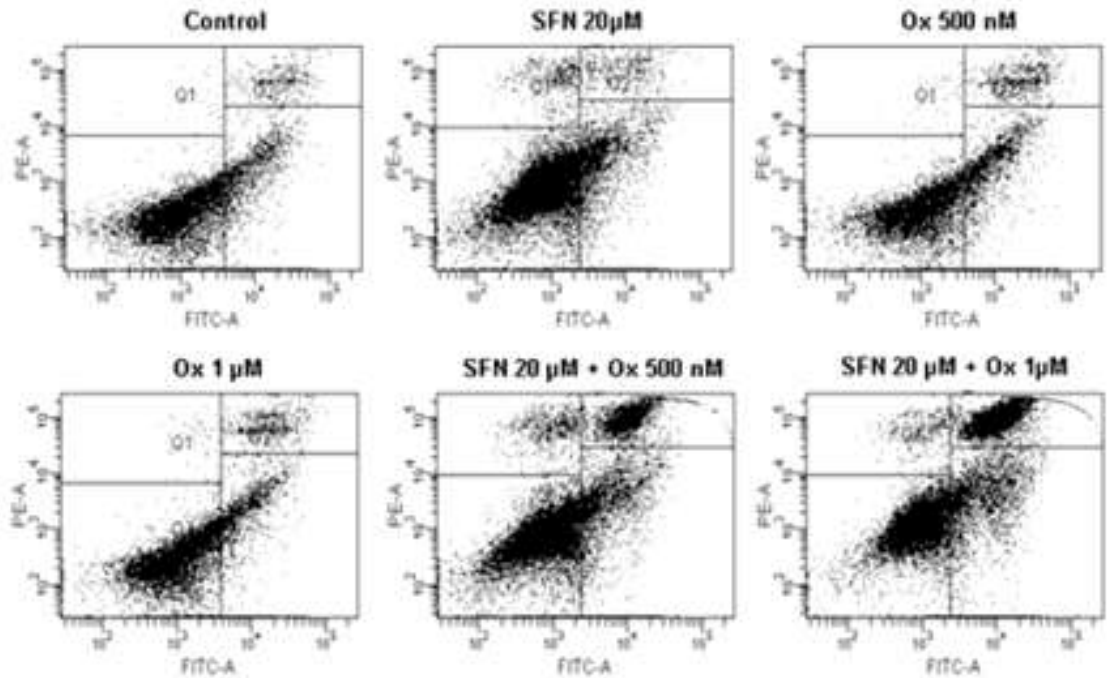

D
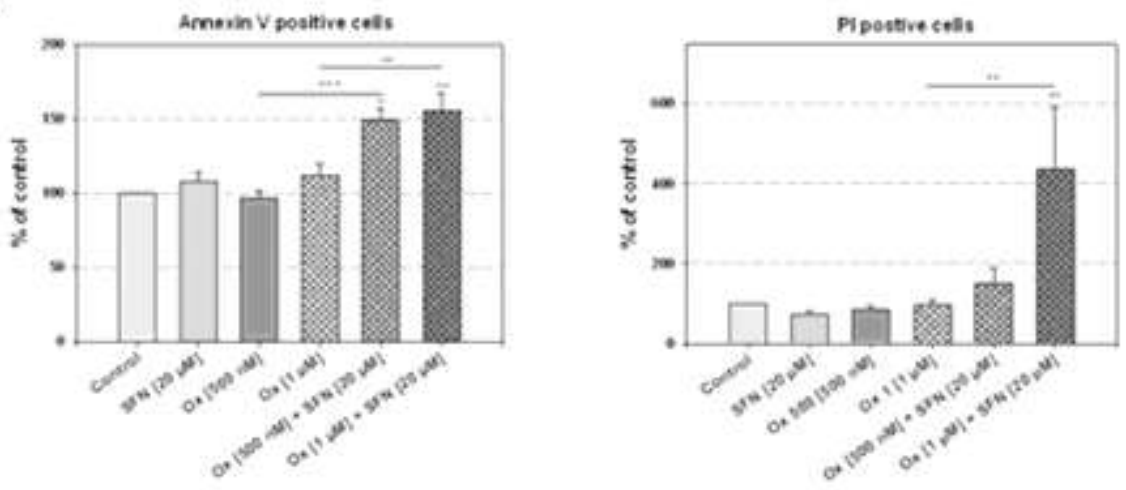
A

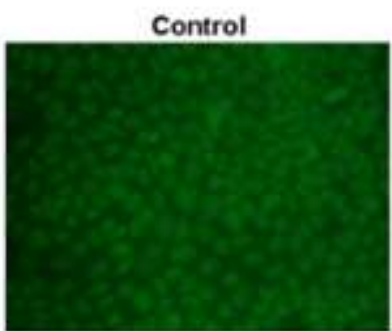

Ox [500 nM]

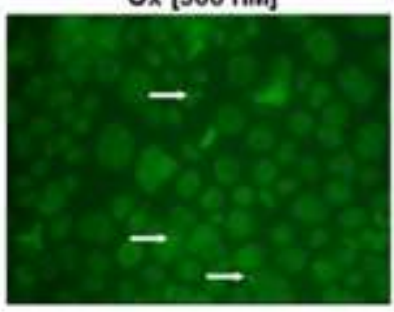

C

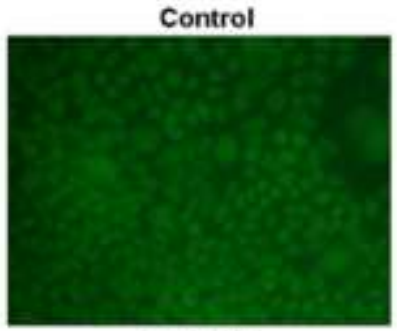

Ox $[1 \mu \mathrm{M}]$

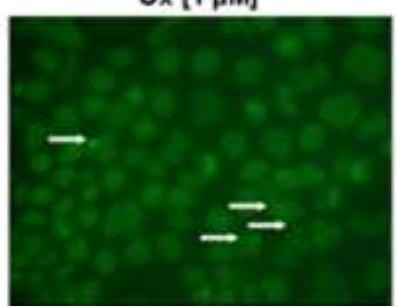

A

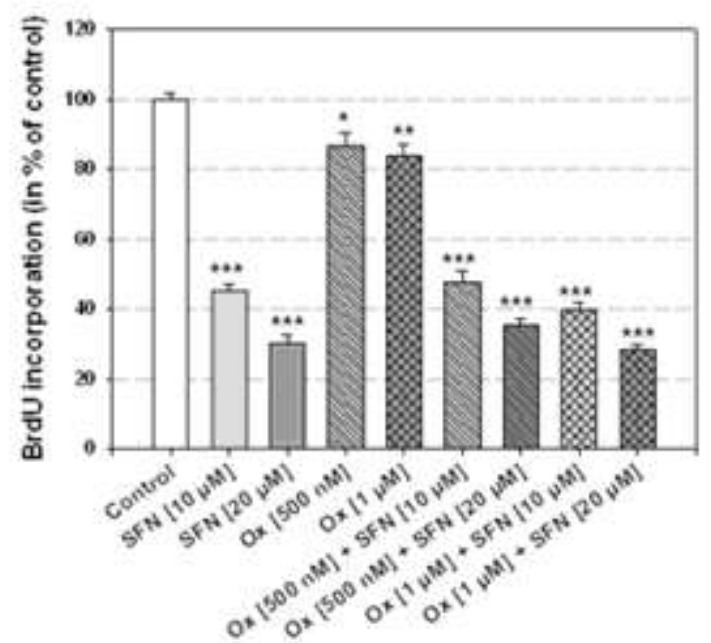

SFN [20 $\mu M]$

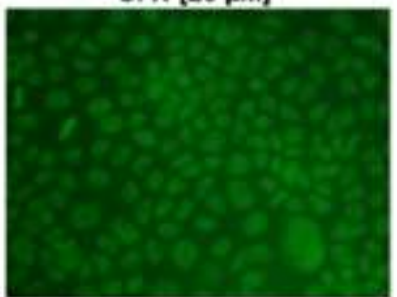

OX $[500 \mathrm{nM}]+$ SFN $[20 \mu \mathrm{M}]$

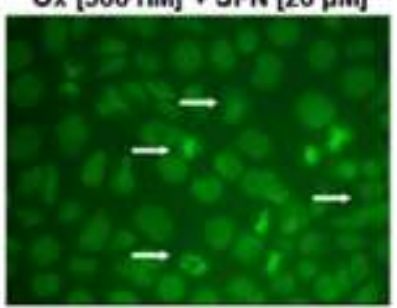

SFN $[20 \mu M]$

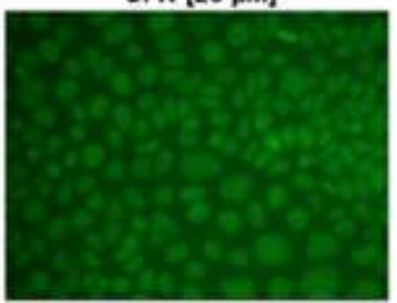

Ox $[1 \mu M]+$ SFN $[20 \mu M]$

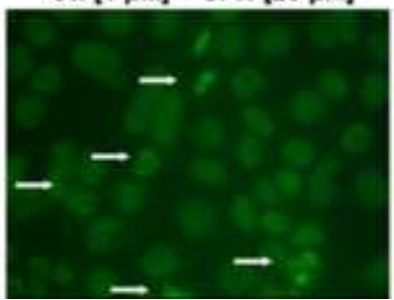

B

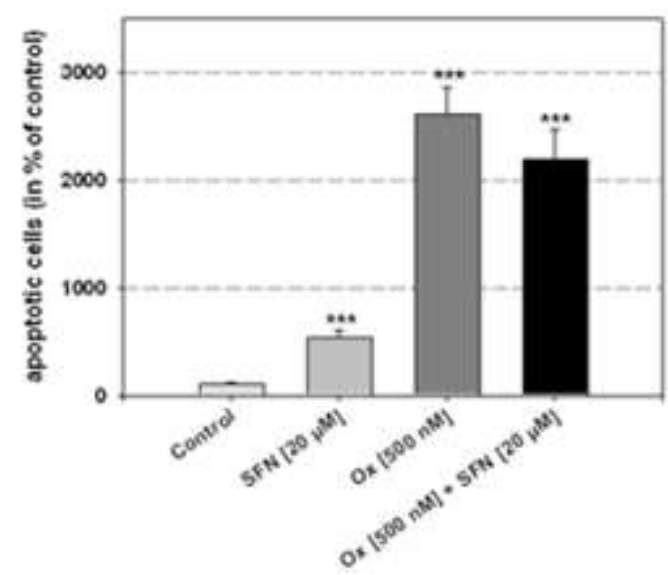

D

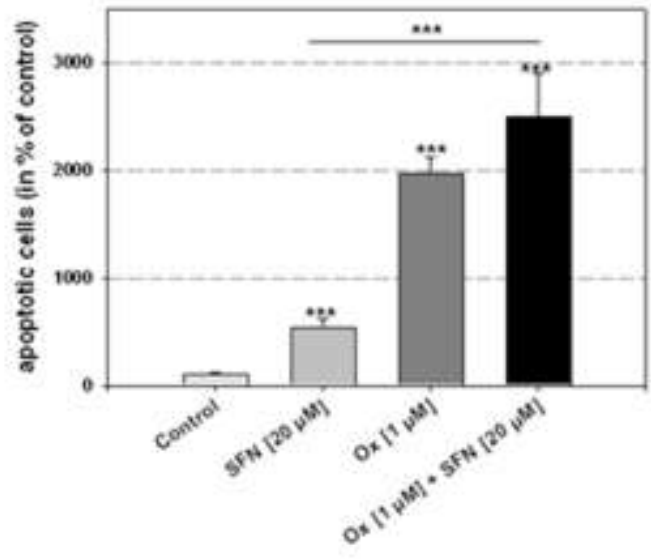

B

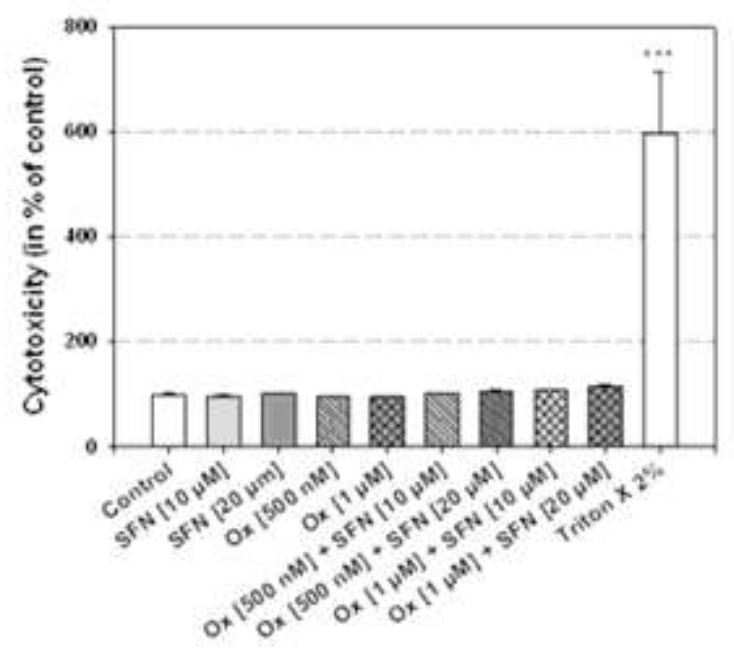

